\title{
Multiple and Concurrent Sexual Partnerships among Mozambican Women from High Socio-Economic Status and with High Education Degrees: Involvement Motives
}

\author{
Germano Vera Cruz ${ }^{1}$, Liria Maússe ${ }^{2}$ \\ ${ }^{1}$ Psychology Department, Faculty of Education, Eduardo Mondlane University, Maputo, Mozambique \\ ${ }^{2}$ Antropology Department, Social Science Faculty, Eduardo Mondlane University, Maputo, Mozambique \\ Email: germane.veracruz@gmail.com
}

Received 29 June 2014; revised 25 July 2014; accepted 12 August 2014

Copyright (C) 2014 by authors and Scientific Research Publishing Inc.

This work is licensed under the Creative Commons Attribution International License (CC BY).

http://creativecommons.org/licenses/by/4.0/

(c) (i) Open Access

\section{Abstract}

The purpose of this study was to discover the motives why certain Mozambican women from high socio-economic status and with high educational level involve in multiple and concurrent sexual partnerships (MCP). Using convenience sampling method, 28 women living in the two Mozambican main cities (Maputo and Beira) were selected to participate in the study and in-depth interviewed. According to the main themes emerged from the participant speeches, it seems that the women of the Mozambican higher society engage in MCP in the framework of power and influence issues that allow them to get help or facilitate the achievement of their business or the development of their professional career. The research also found that one of the reasons for this practice was the lack of sexual pleasure in the marital relationship because their partners do not provide pleasure or give pleasure below their expectations. Another motive for engaging in MCP is a reaction to male domination and male infidelity, a will to transgress the established order and claim a kind of emancipation. Doing that, the participants appear to neglect their biological risk of HIV infection rather to rich their aspirations or maximize their "social capital".

\section{Keywords}

Mozambique, Women, High Status, Multiple Sexual Partnership 


\section{Introduction}

Multiple and concurrent partnerships (MCP) can be described as when an individual has more than one sexual partners at the same period (overlapping partnerships), in contrast with sequential type of sexual relationship.

While the people in southern African countries report on average similar numbers of partners over a lifetime as the people in other world regions do (Epstein \& Morris, 2011); in general, the prevalence of sexual partnership concurrency is higher in this region than that elsewhere (Wellings et al., 2006).

For instance, the mean lifetime number of partners is eight partners for men and four partners for women in USA; 9.3 partners for men and 4.7 partners for women in UK; 11.6 partners for men and 4.4 partners for women in France; three partners for men and women in India, 3.3 partners for men and women in China; six partners for men and 3.8 partners for women in South Africa; eight partners for men and four partners for women in Mozambique (SADC, 2006; Spira \& Bajos, 2006; UK Health and Social Care Information Centre, 2012; The Kinsey Institute, 2010; Vera Cruz, 2007). As for the multiple and concurrent partnerships, for example, in USA, surveys suggest that $11 \%$ of men and $12 \%$ of women in the general population engaged in partner concurrency in the past year and past five years prior to survey, respectively; in France, 13.3\% of men and 5.6\% of women had MCP during the preceding inquiry 12 months; in South Africa, $24.7 \%$ of men and $4.7 \%$ of women had MCP during the year prior to survey; in Mozambique, 28\% of inquired men and 13.7\% of inquired women had MCP during the year prior to survey (Adimora et al., 2002, 2007; Spira \& Bajos, 2006; Steffenson et al., 2011; Tanser et al., 2011; Vera Cruz, 2007).

It must be noted that the practice of men and women having multiple or concurrent sexual partners, which fuels the spread of HIV, has been hypothesized as a cause of higher rates of HIV infection in southern Africa (Epstein \& Morris, 2011; Halperin \& Epstein, 2004; Mah et al., 2010; SADC, 2006; Steffenson et al., 2011).

Naturally, in Mozambique, as elsewhere, the MCP are considered more acceptable when it comes to men who have sexual relationships with multiple concurrent women and less acceptable when it comes to women who have sexual relationships with multiple concurrent men (Adimora et al., 2002, 2007; Carey et al., 2010; Vera Cruz \& Mullet, 2012).

An number of studies suggest that men get involved in overlapping sexual partnerships as a means for having more sexual gratification, to prove their manhood and social power (Carey et al., 2010); women embrace multiple and concurrent partnerships as a way to have a financial, economic and social support for them and their children (Wellings et al., 2006).

Indeed, as it shown in previous study (Loforte, 2000; N’weti, 2008; Vera Cruz \& Mullet, 2012), the majority of Mozambican women involved in overlapping relationships come from low and middle-low socio-economic classes, experiencing financial strain. They used to call their multiple sexual partners the "ministers": the minister of Finance who can provide money; the minister of Health (which can be a doctor or any other hospital worker) who can help her or her family to have quick and efficient medical treatment when needed; the minister of Justice who can advice her our intervene in her fever as for legal issues; the minister of education who help her do school works or cheat on examines, and so on.

\section{Purpose of the Study}

The purpose of this study is to inventor the specific motives driving some Mozambican women from high socioeconomic status and with high education degrees into multiple and concurrent sexual partnerships.

Indeed, although the majority of the Mozambican women involved in MCP are from lower categories of the general population, there are some of them (14\% of the total of women that are involved in MCP) that are high educated, with high socio-economic status and good financial condition. As apparently these women are not seeking material goods from their partners, it seems legitimate to ask why then they engage themselves in this kind of relationship which carries some risk of sexually transmitted infections (STIs) - the HIV prevalence of 15 - 45 years old Mozambican population is 16\%, and in certain cities this rate reaches 26\% (CNCS, 2010).

In fact, sexual liaisons with multiple and concurrent partners have been initially analyzed in term of individual behavior and considered as a way to have more sexual gratification, as well as to explorer virility (men), and as a way to maximize the chances of have materials goods or an economic support for survive (women) (e.g., Wellings et al., 2006). The studies driven by Thornton (2009) led to a shifting scale of the analysis, moving from a perspective focused on the behavior of an individual towards larger-scale structures and institutions which take in account the fact that individual sexual behaviors are at least in partially determined by social structural factors, 
cultural values, and opportunity. In this perspective, sexual liaisons with MCP serve to increase the size and diversity of an individual's social network and therefore to increase their social capital (Thornton, 2009). Social capital is the direct value (in cash, but also in kind, reputation, distinction, self-esteem, etc.) (Bourdieu, 1984; Halpern, 2005).

Thus, by studying the motivations behind the practice of multiple and concurrent sexual partnerships among Mozambican women from high socio-economic status and with high education degrees we hope to unravel the link between MCP and the "social capital” acquisition strategies.

\section{Method}

\subsection{Participants}

Using convenience sampling method, 28 women living in the two Mozambican main cities (Maputo and Beira) were selected to participate in the study, after been indicated and contacted throughout some of our university students who know them personally.

The women were, on average, 30.2 years of age ( $\mathrm{SD}=5.8$ years, range $=22-47$ years). All them had a high school education level; and most of them (91.3\%) had a university degrees (bachelor or/and master). The majority of women were married (84.3\%); and some of them were divorced/separated (7.7\%); widow (5.9\%), single and never married (2.1\%). All of them had a good socio-economic situation, exercising varied profession such as entrepreneurs (eight of them), businesswomen (five of them), bank employees (two of them), lawyers (two of them), accountant (two of them), doctor (one of them), economist (one of them), member of national parliament (one of them), television anchor (one of them), etc. A minority of them (12.5\%) were unemployed (housewives), but with sufficient resources coming from their husbands. The participants reported an average of $2.4(\mathrm{SD}=1.3)$ men partners in the past three months. No one reported having sex with women.

\subsection{Material and Data Collection}

This qualitative study was cross-sectional and exploratory in nature, using in-depth interviews (IDIs) to examine the motives for multiple and concurrent sexual partnerships among Mozambican women from high socio-economic status and with high education degrees.

The interviews were made by authors and two trained female graduate students from the Eduardo Mondlane University.

The tested guides included open-ended questions addressing a variety of topics, including questions in the following domains: definitions and forms of concurrent sexual partnerships; number of partners in concurrency, motivations and justifications for engaging in concurrency; cultural factors that stirs or impede concurrent partnerships; how gender and socialization, and personal socio-economic situation is relate to the issue of MCP. Furthermore, the questions were framed to elicit participant perceptions about how others in their communities behaved and their approval of concurrency.

All interactions with subjects occurred in private locations, without the presence of third parties. The facilitators and interviewers also ensured that the IDIs were held in locations so that no one outside the group or interview could hear the discussion. IDIs lasted between 50 and 90 min and were conducted in Portuguese which is de official language in Mozambique. All IDIs were tape recorded and transcribed in verbatim.

\subsection{Data Analysis}

Data were analyzed thematically in a multi-step process using the constant comparative method.

First, the recorded interviews were transcribed and checked for accuracy. Secondly, two transcripts were chosen for open coding by the analysts. Open coding involves categorizing data in terms of properties; data were examined for code generation and were then reviewed to gain a holistic view of the data. During the open coding process, memos were written to help develop themes that were emerging from the data. The themes were then discussed between the authors and two others independent experts. After that discussion, the team reviewed selected transcripts to verify the codes and finalize the code list. The resulting code list was then used to code the next two transcripts; this step was conducted to assess the similarity as well as the differences among the transcripts. As new themes emerged, the code list was again refined and previously coded IDIs were recoded as necessary. 
After coding was completed, the second author reviewed a selected sample of transcripts to verify themes. The two authors and the two invited independent experts then verified the interpretations and conclusions before the manuscript was drafted.

Data were managed and coded utilizing Atlas-ti @ software, version 6.0.

\section{Results}

The broad themes that emerged included issue of power and influence, marital sexual dissatisfaction, reactive behavior and willingness to emancipation.

\subsection{Issue of Power and Influence}

Speech delivered by the participants in this study gives off that in the framework of their professional activities (particularly in the sphere of business and politics) they enter, consciously or not, in a "game" of alliances, power of influence and/or favoritism. It is in this context that they can have "some friends" (sexual partners) that are useful to them whenever necessary, in "this or that" aspect of their profession in particular and life in general.

For example, one of the interviewed woman, a member of national parliament, 32 years old, divorced (her exhusband decided to separate from her when he learned she was infertile), said:

“Politics has always been a game of power and influence, isn’t it? Why I have several sexual partners? Let me say they are friends that give me a politic grows when I need it... But listen careful, I do not sleep with anyone. These are high-ranking people, and I like them. With them, I can combine the useful with the pleasant...”

Another woman, 36 years old, who owns an apparels and beauty products import and sale company, married, mother of two children, said:

"As part of my professional activities, I travel a lot here in Mozambique and abroad. So I know lots of interesting people. And that's how I ended up wrapping me with a very nice gentleman I met on the plane, during a trip to Brazil, plus another one that I already know to a certain time and that helps me a lot in my business".

One of the respondents aged 42, widow, mother of three, who has three restaurants, suggest that her choice of having MCP is related to a desire of independence as well as a way to fulfill her emotional and professional needs:

"Since the death of my husband, I decided I would not marry more and not want to live with a man... I prefer to be independent at the same time have lovers, people I like but do not live with them. My lovers are very important people with whom I can count both emotionally and professionally...”

Another example of this thematic of power and influence is given by a young interviewee, 26 years old, married, lawyer in a legal advice office, who has an involvement with his boss, as she said:

"I have an affair with my boss for some time now. I admire him greatly. He is so smart and so influential person. I think that's why I fell in love with him. He is married, like me. And that's why we decided to just be lovers... But I must also confess that it is with his support that my career has developed rapidly".

\subsection{Marital Sexual Dissatisfaction}

Another reasons expressed by participants as motivation for involvement with multiple and concurrent partners is sexual dissatisfaction in their marital relationships. Their partner does not provide them pleasure or provide pleasure below their expectations.

In this matter, for instance, one of the interviewed women, 27 years old, accountant, with two children, said:

"For me, sexual satisfaction is feeling very happy and feel in tune with your partner with whom you fuck; is an inner happiness, intrinsic joy that comes from inside and that you feel after having sex".

"I had the misfortune to marry a very religious practitioner. When we have sex we do it quickly and without 
fantasies. No news much less variety... I tried talking to him, but in vain... I cannot climb over him because only prostitutes do it... He use to tell me that God said that sex is to make child and not for pleasure. We do not do any kind of foreplay, just kiss me and he is already inside my vagina".

"That is why I go out looking at other men for my sexual satisfaction, men who know well that it is needed to warm the coffee before taking it...”

Still in this thematic, for example, another woman, a doctor, 45 years old, married to a wealthy businessman, a mother of three, said:

"I really like sex, making love with pretty young men who have a big and thick penis. Now, my husband has a tiny penis and moreover he is old. He cannot satisfy me...”

"For me, a real man should have a big thick and hard cock. Small penis itches only give itching, is like nothing going in my vagina...”

Besides the larger size of the male genital organ, the multiple concurrent partners with whom this respondent is involved need to have regular girlfriends, need to enjoy sadomasochistic sexual practices, and must be needy so that she can help by giving them money or gifts. As she confesses, these particular preferences allow her to demonstrate both her femininity and her socio-economic power.

Another interviewee, 25, housewife, married, mother of one, said:

"My husband and I have been married for five years and started dating for over six years. At first, when we had just met, when I made love with him it was nice. But now, after a long time together, there is no pleasure... Sex became just a ritual... This is the reason that made me start looking for other men with whom I maintain satisfactory sexual intercourse, but without any long term commitment...”

In relation with marital sexual dissatisfaction, one respondent, 36 years old, a bank worker, married, mother of two, also said:

"My husband suffers from premature ejaculation. I talked to him several times for him to go see a specialist, but he doesn’t accept... I endured this situation for a long-time, living in frustration. But when I turned 35, and after the number of children I wanted, a life well-done; I decided that I deserve to have a pleasure in my life, to be flushed and happy: so I am going to date other men...”

One of the common ground in the participant discourses is that they do not wish to separate from their husbands despite the fact that they do not satisfy them sexually. Therefore, they are discrete on their infidelity, and in the majority of case they use to choose extramarital lovers that they like, but without great sentimental commitments.

\subsection{Reactive Behavior, Revenge and Willingness to Emancipation}

Another motive for multiple and concurrent sexual partnerships identified by this research is related to the reactive behavior of women in relation with the problems occurring in the marital relationship, as well as the desire to emancipate themselves from traditional religious and socio-cultural values that perpetuate male domination.

In this matter, one of the problems for the reactive behavior by the women studied is marital infidelity they suffered, as in the following testimony, given by an interviewee of 41 years old, married, housewife and mother of four children:

"I found my husband with another woman in a garden, kissing... I later learned that he had affairs with many other women... At first I was sad and desperate, but then decided to do the same thing. I started to get involved with other men as a way of showing that there are men who might want me and love me to my fair value, in spite of my age; and also to prove that I could also behave like a men... Later, I began to like it and take great pleasure from my multiple partners..."

Another woman, 30 years old, who works as a trainer in a gym, mother of one, said:

"One of these days, I learned that my husband had mistresses and he even had a child with one of them. Then I thought to myself, why men make love with several women and we women have to behave like a holy suffering and accepting their infidelity? So I decided to do the same thing...” 
In this theme, one of the interviewees, 43 years old, housewife, mother of two, said he started getting involved with other men as a reaction to sexist behavior from her husband:

"My husband is a big macho. It controls my every move, at the same time he grants himself the luxury of doing whatever he want and even dating other women. He is who decides on everything at home. And he does everything for me to be physically and socially dependent on him. So I wanted to show that I'm smarter than him. I leave him dominate and humiliate me, without apparently say nothing against; while discreetly I take my revenge, going to fuck several men...”

Feeling dissatisfied with the sexual performance of their husbands or angry by the unfaithfulness of these, why these women are not opting for divorce and seek other husbands that suit them best?

We can answer this question evoking certain socio-cultural factors. First, in the Mozambican context, as in others, for women, socio-economic factors play a major role in choosing husbands, preferring to marry man whose level of material wealth and social status enables them to increase or at least maintain they own capital (Gagnon \& Simon, 1973; Bourdieu, 2001, 1984; Vera Cruz, 2007). Second, they think that changing husband is not worth because in that aspect, married men behave against their wives almost all of them in the same way, so that another husband would not change much their situation. Finally, third, in the Mozambican context, a divorced woman and that is not young have more difficulties to find a husband comparatively to younger women who have never married (Vera Cruz, 2007).

In this regard, one interviewee, 29 years old, head of the marketing department at a tour company, married and mother of two, said:

"Divorcing? No, no. With my husband, I have kids and an economically secure life. Moreover, here the men are all alike, are sexist, after a certain time of marriage, they have no interest in making love to their wife, and they all cheat on them".

\subsection{Fatalism Regarding the Risk of HIV Infection}

All women claim to be well-informed about the pandemic of HIV/AIDS, means of transmission/infection and the high level of HIV prevalence in Mozambique. However, 27\% of them admitted to having had at least one unprotected sexual intercourse with some of their multiple extramarital sexual partners (this percentage is slightly lower than the percentage-32\% - of women of low socio-economic status who reported also not have used a condom at least one time, during sex with their multiple concurrent partners [Vera Cruz \& Mullet, 2012]).

In fact, regarding the issue of HIV/AIDS, as in the sexually active Mozambican population in general (Vera Cruz \& Mullet, 2012), a certain fatalism detaches itself from the discourse of most interviewees. They tend to think that one should do "everything possible" to avoid contamination, but given the socio-cultural context in which they live and the high levels of HIV prevalence, it is also needed "to be very lucky" to avoid infection.

For example, one interviewee said in this regard:

"Of course I fear the contamination and I seek to prevent myself... But in matters of sexuality, it is difficult to control everything and always what can happen at the precise moment of the sexual act... Well, you cannot spend your life living in fear, otherwise life becomes unbearable! Moreover, in this country where almost all men are unfaithful and go out with lovers and often without condoms, many women who are faithful run the risk of being infected by their own husband. I know women who live as saints, but still were contaminated by the husbands who were cheating on them...”

\section{Discussion}

The low socio-economic level, low schooling and the consequent difficulties in meeting basic needs have been referenced by some authors as a factor catalyst for the involvement of women in multiple and concurrent sexual relationships (Loforte, 2000; Nweti, 2009; Vera Cruz \& Mullet, 2012). Although it is true that most women who engage in MCP come from the poorest sections of society, there are also a number of women of high socioeconomic classes and high educational level engaged in the same kind of sexual relationships.

Thus, the aim of this study was to try to discover the reasons why women of high socio-economic and educational level involve in multiple and concurrent sexual relations.

The findings suggest that certain women of the Mozambican higher society engage in MCP in framework of 
power and influence "games" that allows them to get help or facilitating the achievement of their business or the development of their professional career.

In these cases, women seem to need "sponsors" to succeed in a field (business or politics) that is traditionally reserved for men. In fact, in Mozambique, while the informal economy is dominated by women, sectors of the formal economy and politics are dominated by men; being that many women entrepreneurs face cultural, administrative and banking barriers when seeking to pass from the informal sector to the formal sector (INE, 2012).

This research also found that one of the reasons for the practice of MCP was the lack of sexual pleasure in the marital relationship because their partners do not provide pleasure or give pleasure below their expectations. Another reason for engaging in MCP is a reaction to male domination and infidelity.

In this regard, it must be noted that, firstly, the involvement with MCP is a way to expand their sexual horizons as well as fulfill their erotic fantasies. Secondly, given the Mozambican patriarchal macho context, MCP of Mozambican women from high socio-economic status is linked to the willingness to transgress the established order fixed my men, a will to claim a certain women emancipation and social gender equality.

Even if the connection between the MCP and the will of emancipation may seem strange, the fact is that sex can be used, consciously or unconsciously, not only as a form (fantasy) of domination, but also as a form of revenge, vindication or an attempt to emancipation (e.g., Beauvoir, 1949; Bourdieu, 2001).

Remember that in the Europe of eighteenth, nineteenth and early twentieth century, some libertine women of the nobility and the bourgeoisie became involved with multiple sexual partners, in some cases, as a way to increase or preserve their "social capital"; in other cases as a way to transgress the established order or to emancipate themselves from the dominant religious and socio-cultural values (e.g., the famous French women Ninon de Lenclos, Madame de Stael and Simone de Beauvoir, the famous English woman Elizabeth Chudleigh, the famous Russian woman Alexandra Kollontai, etc.).

Finally, if we interpret this result in light of the Maslow (1943) theory of human motivation, we can say that, while women from low socio-economic status engage in MCP to meet their basic needs (food, shelter, protection, etc.), women from high socio-economic level engage in MCP to satisfy higher needs (pleasure/love, recognition, self-fulfillment, etc.).

If we interpret these results in terms of the theory of sexual network as a means of maximizing "social capital" (Thornton, 2009), we can say both women of low socio-economic status and those from high socio-economic status who engage in MCP do it for, consciously or not, maximizing the chances of developing, maintaining or achieving their aspirations, their potential; the difference lies in the form and the kind of each group aspirations.

Doing that, many Mozambican sexually active women of both social classes appear to neglect their biological risk of HIV infection rather to rich their aspirations or to maximize their "social capital".

\section{References}

Adimora, A. A., Schoenbach, V. J., \& Doherty, I. A. (2007). Concurrent Sexual Partnerships among Men in the United State. American Journal of Public Health, 97, 2230-2237. http://dx.doi.org/10.2105/AJPH.2006.099069

Adimora, A. A., Schoenbach, V. J., Bonas, D. M., Martinson, F. E., Donaldson, K. H., \& Stanci, T. R. (2002). Concurrent Sexual Partnerships among Women in the United State. Epidemiology, 13, 320-327. http://dx.doi.org/10.1097/00001648-200205000-00013

Bourdieu, P. (2001). Masculine Domination. Cambridge: Polity Press.

Bourdieu, P. (1984). Distinction: A Social Critique of the Judgment of Test. Cambridge: Harvard University Press.

Beauvoir, S. (1949). Le deuxième sexe [The Second Sex]. Paris, France: Gallimard.

Carey, M. P., Senn, T. E., Seward, D. X., \& Vanable, P. A. (2010). Urban African-American Men Speak out on Sexual Partner Concurrency: Findings from a Qualitative Study. AIDS and Behavior, 14, 38-47. http://dx.doi.org/10.1007/s10461-008-9406-0

CNCS (2010). Plano Estratégico Nacional de Combate ao HIV/SIDA 2010-2015. Maputo, Mozambique: CNCS.

Epstein, H., \& Morris, M. (2011).Concurrent Partnerships and HIV: An Inconvenient Truth. Journal of the International AIDS Society, 14, 13. http://dx.doi.org/10.1186/1758-2652-14-13

Gagnon, J., \& Simon, W. (1973). Sexual Conduct. Chicago: Aldine.

Halpern, D. (2005) Social Capital. Cambridge: Polity Press. 
Halperin, D. T., \& Epstein, H. (2004). Concurrent Sexual Partnership Help to Expalin Afric’s High HIV Prevalence: Implication for Prevention. The Lancet, 364, 4-6. http://dx.doi.org/10.1016/S0140-6736(04)16606-3

INE (Mozambican Institute for Statistic) (2012). Mozambican Economic Outlook. Maputo: INE.

Loforte, A. (2000). Género e poder entre os Tsongas de Moçambique [Gender and Power among the Tsongas of Mozambique]. Maputo: Edições Promédia.

Mah, T. L., \& Halperin, D. T. (2010). Concurrent Sexual Partnerships and the HIV Epidemics in Africa: Evidence to Move Forward. AIDS and Behavior, 14, 11-16. http://dx.doi.org/10.1007/s10461-008-9433-x

Maslow, A. (1943). A Theory of Human Motivation. Psychological Review, 50, 370-396. http://dx.doi.org/10.1037/h0054346

N'weti (2008). Silêncio, segredos e mentiras: Relatório de pesquisa de audiência sobre parceiros múltiplos e concorrentes [Silence, Secrets and Lies: Report of Audience Research about Multiple Partners and Competitors]. Maputo: N'weti.

SADC (2006). Expert Think Tank Meeting on HIV Prevention in High-Prevalence Countries in Southern Africa. Maseru: SADC.

Spira, A., \& Bajos, N. (2006). Les comportements sexuels en France [Sexual Behavior in France]. Paris: Editions de la Documentation Française.

Steffenson, A. E., Pettifer, A. E., Seage, G. R., Rees, H. V., \& Cleary, P. D. (2011). Concurrent Sexual Partnership and HIV Risk among South African Youth. Sexual Trabsmitted Disease, 38, 459-466.

Tanser, F., Bärnighausen, T., Hund, L., Garnett, G. P., McGrath, N., \& Newell, M. L. (2011). Effet of Concurrent Sexual Partnerships on Rate of New HIV Infection in a High-Prevalence, Rural South African Population: A Cohort Study. The Lancet, 378, 247-255. http://dx.doi.org/10.1016/S0140-6736(11)60779-4

Thornton, R. (2009). Sexual Networks and Social Capital: Multiple and Concurrent Sexual Partnerships as a Rational Response to Unstable Social Networks. African Journal of AIDs Research, 8, 413-421. http://dx.doi.org/10.2989/AJAR.2009.8.4.5.1042

The Kinsey Institute (2010). National Survey of Sexual Health and Behavior. Indiana: KI.

UK Health and Social Care Information Centre (2012). Health Survey for England-2011, Health, Social Care and Lifestyles. London: NS.

Vera Cruz, G., \& Mullet, E. (2012). Sexual Attitudes among Mozambican Adults. International Journal of Psychology and Counselling, 4, 73-80.

Vera Cruz, G. (2007). Les attitudes sexuelles des Mozambicains. Comparaison avec les attitudes sexuelles des Français [Mozambican Sexual Attitudes. Comparison with French Sexual Attitudes]. Lille: Anrt.

Wellings, K, Collumbien, M., Slaymakcr, E., Singh, S., Hodges, Z., Patel, D., \& Bajos, N. (2006). Sexual Behaviour in Context: A Global Perspective. The Lancet, 368, 1706-1728. http://dx.doi.org/10.1016/S0140-6736(06)69479-8 
Scientific Research Publishing (SCIRP) is one of the largest Open Access journal publishers. It is currently publishing more than 200 open access, online, peer-reviewed journals covering a wide range of academic disciplines. SCIRP serves the worldwide academic communities and contributes to the progress and application of science with its publication.

Other selected journals from SCIRP are listed as below. Submit your manuscript to us via either submit@scirp.org or Online Submission Portal.
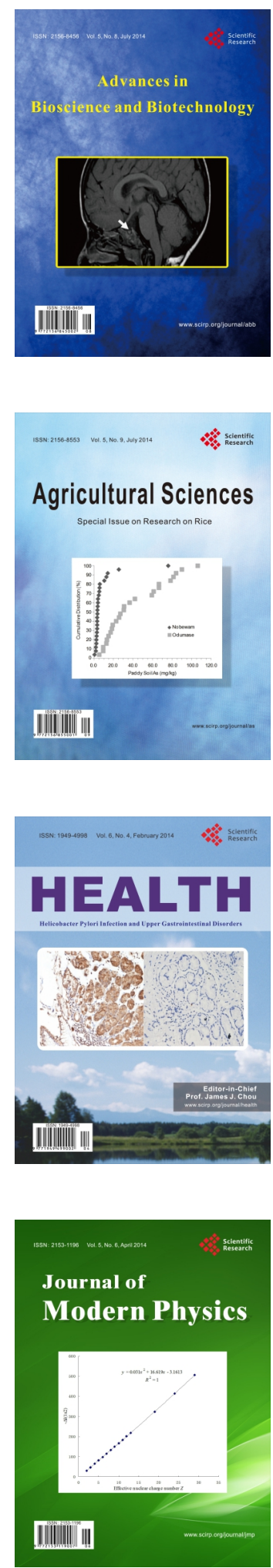
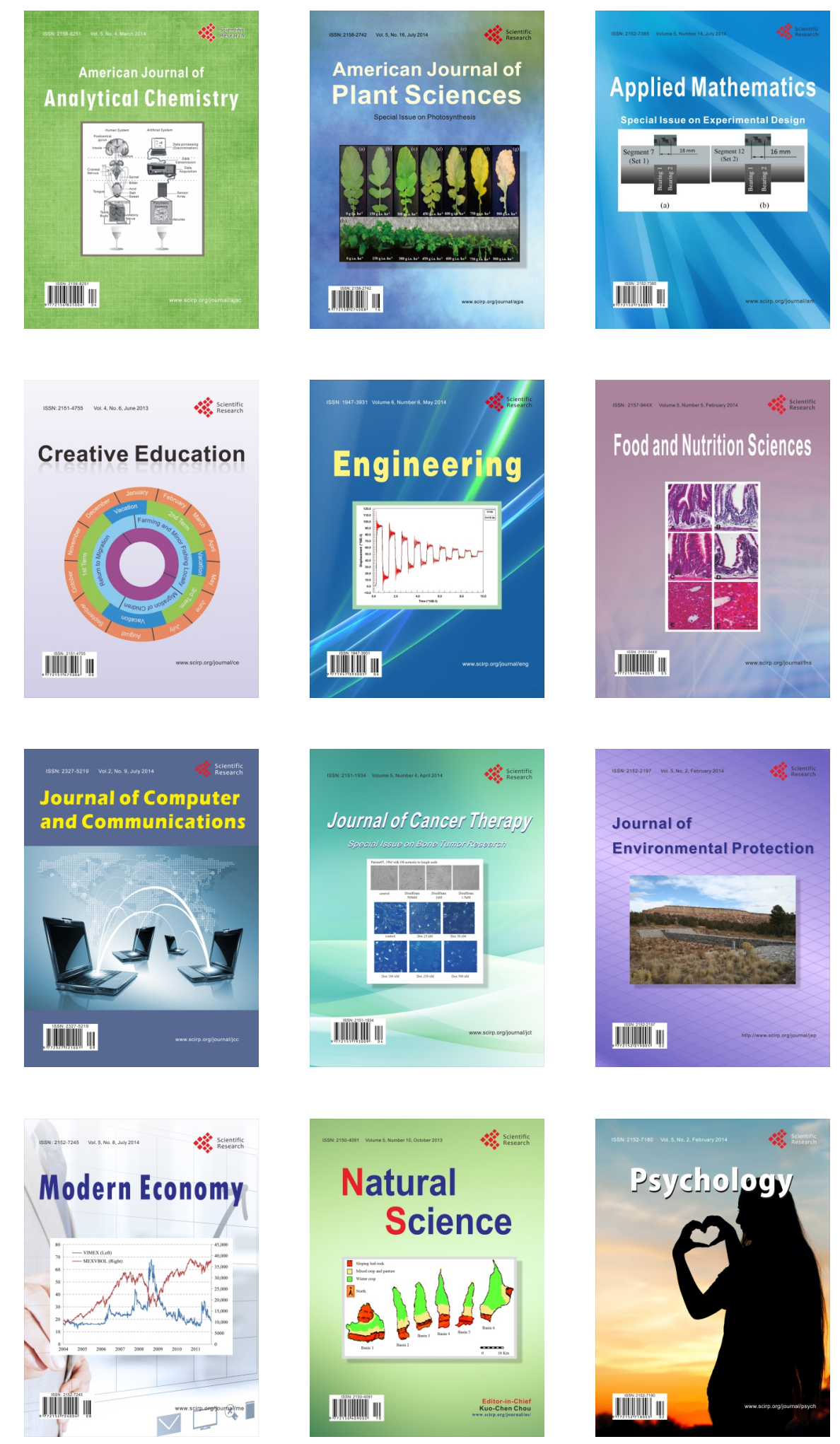